\title{
ADVANTAGES OF SUPPORTS ACTIVATED WITH DIVINYL SULFONE IN ENZYME CO-IMMOBILIZATION: POSSIBILITY OF MULTIPOINT COVALENT IMMOBILIZATION OF THE MOST STABLE ENZYME AND IMMOBILIZATION VIA ION EXCHANGE OF THE LEAST STABLE ENZYME
}

Roberto Morellon-Sterling ${ }^{1,+}$, Diego Carballares ${ }^{1,+}$, Sara Arana-Peña1, El-Hocine Siar $^{1,2}$, Sabrina Ait Braham ${ }^{1,3}$, Roberto Fernandez-Lafuente, ${ }^{1,4, *}$

1. Departamento de Biocatálisis. ICP-CSIC, C/ Marie Curie 2, Campus UAM-CSIC Cantoblanco, Madrid 28049, Spain.

2. Transformation and Food Product Elaboration Laboratory, Nutrition and Food Technology Institute (INATAA), University of Brothers Mentouri Constantine 1, 7 ème Km Constantine 25000, Constantine 25000, Algeria.

3. Laboratoire de Biotechnologies Végétales et Ethnobotanique, Faculté des Sciences de la Nature et de la Vie, Route de Targa Ouzemmour, Université de Bejaia, 06000 Bejaia, Algeria.

4. Center of Excellence in Bionanoscience Research, External Scientific Advisory Academic, King Abdulaziz University, Jeddah 21589, Saudi Arabia.

This supporting information include 2 pages with two Figures (Figures 1S and 2S). 


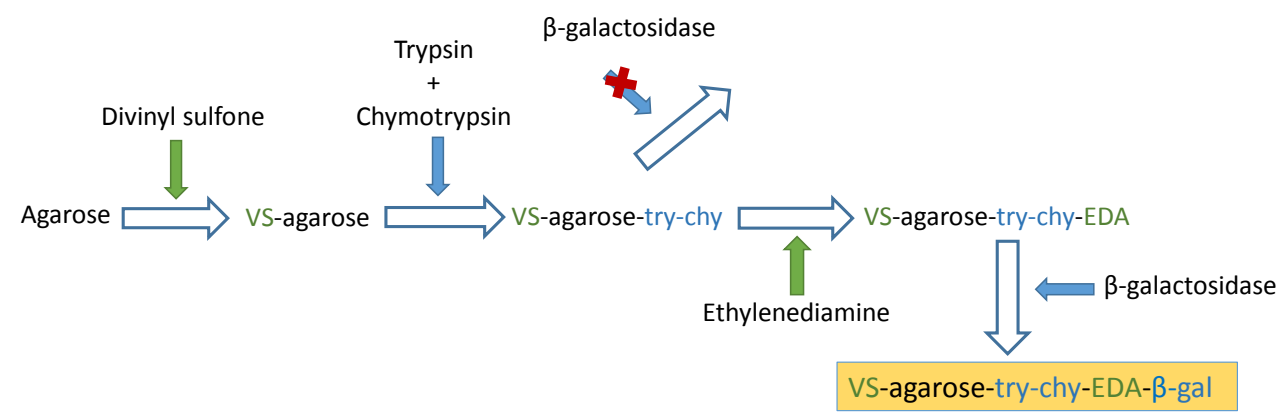

Figure 1S

Figure 1S: Flow-chart of the co-immobilization of trypsin, chymotrypsin and $\beta$ galactosidase on vinyl sulfone agarose. 




Figure 25

Figure 2S: Flow-chart of the co-immobilization of trypsin and ficin on vinyl sulfone agarose. 